\title{
STUDIES ON THE CHEMOTHERAPY OF THE HUMAN MALARIAS. IV. THE METABOLISM OF CINCHONINE IN RELATION TO ITS ANTIMALARIAL ACTIVITY 1, 2,
}

\author{
By DAVID P. EARLE, JR., WILLIAM J. WELCH,4 and JAMES A. SHANNON \\ (From the Department of Medicine, New York University College of Medicine, and the \\ Research Service, Third [New York University] Medical Division, \\ Goldwater Memorial Hospital, New York City)
}

(Received for publication March 12, 1947)

The study of the host metabolism of a chemical agent has both theoretical and practical interest in any consideration of chemotherapeutic action. Metabolic change can modify chemotherapeutic effect through a conversion of an active to an inactive agent or through a conversion of an inactive to an active agent. Or activity itself may in some way be associated with the process of metabolism. The cinchona alkaloids were selected for special study since it appeared that they offered a good opportunity to obtain information which might bear on these generalizations. The cinchona alkaloids are extensively metabolized by the tissues of man and certain animals $(1,2,3)$, their fate being primarily determined by the rate of their metabolic alteration (4).

A number of metabolic products formed in man from quinine, quinidine, cinchonine and cinchonidine have been isolated ( 3 ) and some, characterized $(3,5)$. When administered to human subjects, cinchonine is metabolized much more rapidly than any of the other cinchona alkaloids, with

\footnotetext{
1 The work described in this paper was done under a contract, recommended by the Committee on Medical Research, between the Office of Scientific Research and Development and New York University.

2 Portions of this work were presented at the meetings of the Federation of American Societies for Experimental Biology, March 11-15, 1946, Federation Proc., 1946, 5, 175 and 214, and were also discussed in a Harvey Lecture by Dr. James A. Shannon, Oct. 25, 1945. Permission to use Table VI has been obtained from the Harvey Society.

3 The authors express their thanks to the Malaria Study Section of the National Institute of Health for editorial assistance and for arrangements in regard to the publication of this paper. They are also grateful to the Abbott Laboratories, E. I. du Pont de Nemours and Company, Inc., E. R. Squibb and Sons, Eli Lilly and Company, Sharp and Dohme, and Wyeth, Inc., for contributing toward the publication costs.

Captain, MC, AUS.
}

the production of large amounts of 2-hydroxy cinchonine (cinchonine carbostyril), and smaller amounts of a further oxidation product. The latter appears to be a derivative of 2-hydroxy cinchonine with an additional oxygen in the quinuclidine portion of the molecule $(3,5)$.

\section{MATERIALS AND METHODS ${ }^{5}$}

With the exception of a few studies on patients with active vivax malaria, the data on the physiological disposition of cinchonine and 2-hydroxy cinchonine were collected from experiments performed in normal volunteers.

The per cent of various amounts of cinchonine and its 2-hydroxy derivative bound on plasma albumin was determined by a technique previously described (6). Absorption from the gastro-intestinal tract was examined by determining the amount of drug excreted with the feces per 24 hours while the subjects were receiving serial oral doses. This procedure yields valid figures since neither cinchonine nor the 2-hydroxy compound was destroyed when incubated at $37^{\circ} \mathrm{C}$. for 24 hours in a mixture of feces. Renal excretion was determined through the use of 24-hour collections of urine while subjects were receiving cinchonine or its 2 -hydroxy derivative. The completeness of urine collections was checked by serial determination of creatinine excretions. The renal clearances of cinchonine and 2-hydroxy cinchonine were determined over periods of one hour. Forty-five minutes prior to each clearance, the subject was given $500 \mathrm{ml}$. of water by mouth. The relation between oral dosage of cinchonine and its 2-hydroxy derivative and the resulting plasma drug levels was determined from the average plasma drug concentrations of the last three of four or five days on serial dosage. Blood samples were obtained three hours after the first daily dose.

The antimalarial activity of 2-hydroxy cinchonine was examined in five patients with blood-induced McCoy strain vivax malaria in accordance with standard procedure previously outlined (7). Briefly, 2-hydroxy cinchonine was administered by dosage schedules which produce

5 The 2-hydroxy cinchonine utilized in these studies was isolated by Dr. B. B. Brodie and J. E. Baer from the urine of normal human volunteers who were receiving large oral doses of cinchonine. 
fairly stable plasma drug concentrations during the fourday therapeutic period. The therapeutic results are classified in three groups: Class I, no certain effect; Class II, a temporary suppression of parasitemia and/or fever; and Class III, a "permanent" effect, i.e., an absence of parasitemia for 14 days, followed by a positive reinoculation to demonstrate continuing host-susceptibility to the infection.

\section{Chemical methods ${ }^{6}$}

A. Cinchonine. The concentration of cinchonine in biological fluids is measured by a method that is specific in that metabolic products of cinchonine are excluded (8).

B. 2-Hydroxy-cinchonine. 2-hydroxy cinchonine is separated from the biological material by extraction into ether at $\mathrm{pH} 10$. About 80 per cent of the compound is extracted by this procedure, the exact amount depending on the relative volumes of the two phases and on the temperature. The distribution coefficient, however, is not greatly affected by small changes in temperature. The ether phase is evaporated to dryness and the residue taken up in ethylene dichloride. The ethylene dichloride is shaken with methyl orange solution at $\mathrm{pH} 5$. The methyl orange, which dissolves in the solvent through salt formation with the 2-hydroxy cinchonine, is measured photometrically.

The levels estimated by the method described for 2hydroxy cinchonine must be corrected for cinchonine where it is present.

Reagents:

1. Standard 2-hydroxy cinchonine (10 mgm. per 100 ml.). Ten mgm. of the free base are dissolved in 100 ml. of $0.01 \mathrm{~N} \mathrm{H}_{2} \mathrm{SO}_{4}$. Working standards are prepared by dilution of this solution with $0.01 \quad \mathrm{~N} \mathrm{H}_{2} \mathrm{SO}_{4}$. The standard solutions deteriorate slightly after three to four days and it is therefore advisable to make fresh standards at least twice a week.

2. Borate buffer- $\mathrm{pH} 10$. To $50 \mathrm{ml}$. of $0.2 \mathrm{M}$ boric acid in $0.2 \mathrm{M} \mathrm{KCl}$ add $43.9 \mathrm{ml} .0 .2 \mathrm{~N} \mathrm{NaOH}$ and dilute to $200 \mathrm{ml}$. with water.

3. $1 \mathrm{~N} \mathrm{NaOH}$.

4. Ether. A reagent grade of absolute ether is purified by washing with an equal volume of $1 \mathrm{~N} \mathrm{HCl}$ followed by three washes with water.

5. Ethylene dichloride containing 1 per cent ethanol. A technical grade of ethylene dichloride is purified by successive washings with equal volumes of $1 \mathrm{~N} \mathrm{NaOH}$ and $1 \mathrm{~N} \mathrm{HCl}$, followed by two washings with water. One per cent by volume of ethanol is added.

6. Alcoholic $\mathrm{H}_{2} \mathrm{SO}_{4}$. Two per cent (by volume) concentrated $\mathrm{H}_{2} \mathrm{SO}_{4}$ in alcohol.

7. Methyl orange solution. Dissolve $90 \mathrm{mgm}$. of the sodium salt of methyl orange in $100 \mathrm{ml}$. of $0.5 \mathrm{M}$ boric acid solution by gentle heating. Cool the solution to

\footnotetext{
${ }^{B}$ The authors acknowledge with thanks the advice and assistance of $\mathrm{Dr}$. B. B. Brodie in the development of the method for the measurement of 2-hydroxy cinchonine concentration.
}

room temperature and filter if necessary. Wash the solution several times by shaking with an equal volume of ethylene dichloride.

\section{Procedure:}

To $5 \mathrm{ml}$. of plasma in a $60 \mathrm{ml}$. glass-stoppered bottle add $1 \mathrm{~N} \mathrm{NaOH}$ until the $\mathrm{pH}$ is about 10 (test with hydrion paper). This usually requires $0.1 \mathrm{ml}$. of $\mathrm{NaOH}$. In the case of urine, add $4 \mathrm{ml}$. of $\mathrm{pH} 10$ borate buffer to $1 \mathrm{ml}$. of urine, diluted if necessary. Then add $30 \mathrm{ml}$. of ether and shake for 15 minutes on a shaking apparatus. Allow the phases to separate, centrifuging the bottle if necessary. Transfer $20 \mathrm{ml}$. of the ether to another glassstoppered bottle and evaporate to dryness on a water bath. Dissolve the residue in $10 \mathrm{ml}$. of alcoholic ethylene dichloride, add $0.5 \mathrm{ml}$. of methyl orange solution, and shake for five minutes. Transfer the contents to a $25 \mathrm{ml}$. test tube and centrifuge for ten minutes at 3000 r.p.m. Carefully remove all the supernatant layer by aspiration, decant the ethylene dichloride phase into another test tube, and recentrifuge for five minutes. Pipette $10 \mathrm{ml}$. of the ethylene dichloride into a colorimeter tube containing $2 \mathrm{ml}$. of the alcoholic $\mathrm{H}_{2} \mathrm{SO}_{4}$ and mix thoroughly. Read in the colorimeter at $540 \mathrm{~m} \mu$.

The reagent blank in which water is substituted for plasma is run through the same procedure and is used for setting the instrument to zero optical density.

Standard curve :

Working standards are prepared by taking $1 \mathrm{ml}$. of standard solution, adding $4 \mathrm{ml}$. of the borate buffer and $30 \mathrm{ml}$. of ether and handling in the same manner as for the plasma and urine determination. Standards are run concurrently with each set of determinations to compensate for variations in the distribution coefficient of 2 hydroxy cinchonine between water and ether at different temperatures.

Calculation of results :

$A$. When no cinchonine is present

$\frac{R_{*}}{R_{\text {f }}} \times \mathrm{A}, \times \frac{1}{\text { ml. sample }}$

$=$ mgm. of 2-hydroxy cinchonine in 1 liter of fluid

where $R_{\mathrm{w}}=$ optical density unknown.

$R_{\mathbb{a}}=$ optical density standard.

$A_{0}=$ micrograms of 2-hydroxy cinchonine in standard.

\section{$B$. When cinchonine is present}

$$
\begin{aligned}
& \frac{R_{*}-K Y}{R_{0}} \times A_{0} \times \frac{1}{5} \\
& \quad=\text { mgm. of } 2 \text {-hydroxy cinchonine in } 1 \text { liter of fluid }
\end{aligned}
$$

where $R_{\mathrm{w}}=$ optical density unknown.

$R_{\mathrm{s}}=$ optical density standard.

$A_{8}=$ micrograms of 2-hydroxy cinchonine in standard.

$K=$ optical density resulting from $1 \mu \mathrm{g}$. cinchonine in $5 \mathrm{ml}$. of $0.1 \mathrm{~N} \mathrm{H}_{2} \mathrm{SO}_{4}$, alkalinized and run through the 2-hydroxy cinchonine procedure.

$Y=$ micrograms cinchonine per liter of sample, as determined by the benzene method. 
Sensitivity and precision:

An optical density of about 0.200 is obtained on the Coleman Model 6 spectrophotometer when $20 \mu \mathrm{g}$. of 2-hydroxy cinchonine is carried through the procedure. Known amounts of the compound added to plasma are recovered with an error of \pm 5 per cent both in the presence and absence of cinchonine. There is a small plasma blank which, for $5 \mathrm{ml}$. plasma, ranges in optical density from .007 to .046 with a mean of .015 . The blank for urine is negligible in relation to the large amount of 2-hydroxy cinchonine.

\section{RESULTS}

Gastro-intestinal absorption. Two to 3 per cent of administered cinchonine or its 2 -hydroxy derivative can be recovered in the feces of subjects who receive 2 or 3 grams of either compound daily in serial oral dosage. This indicates almost complete absorption of both compounds.

Plasma protein binding. Both cinchonine and 2-hydroxy cinchonine are bound to a considerable extent on non-diffusible constituents of plasma, presumably the albumin fraction. At a plasma drug concentration of $2 \mathrm{mgm}$. per liter and a plasma albumin content of 4 grams per $100 \mathrm{ml}$., 60 per cent of cinchonine and 52 per cent of 2 hydroxy cinchonine are bound. These observations were made at $37^{\circ} \mathrm{C}$. and a $\mathrm{pH}$ of 7.4. At lower plasma drug concentrations the per cent bound is greater, although accurate results could not be obtained because the methods of analysis were not sensitive enough.

Relation between serial oral dosage and plasma drug levels. Plasma drug levels achieved on serial oral dosage of cinchonine and its 2 -hydroxy derivative are summarized in Table I. Considerably higher levels are achieved by 2-hydroxy cinchonine than by equal doses of cinchonine. This is especially striking at the lowest dose studied.

TABLE I

Relation between serial oral dosage of cinchonine $(C)$ and 2-hydroxy cinchonine (CMP) and plasma drug levels

(Plasma drug levels represent average of last three of four to six days on drug)

\begin{tabular}{c|c|c|c|c}
\hline \hline \multirow{2}{*}{$\begin{array}{c}\text { Daily } \\
\text { dose }\end{array}$} & \multicolumn{2}{|c|}{ Cinchonine } & \multicolumn{2}{c}{ 2-Hydroxy cinchonine } \\
\cline { 2 - 3 } \cline { 5 - 6 } & $\begin{array}{c}\text { Number of } \\
\text { subjects }\end{array}$ & $\begin{array}{c}\text { Mean } \\
\text { plasma } \\
\text { C level }\end{array}$ & $\begin{array}{c}\text { Number of } \\
\text { subjects }\end{array}$ & $\begin{array}{c}\text { Mean } \\
\text { plasma } \\
\text { CMP level }\end{array}$ \\
\hline grams & 10 & mgm./L & & mgm./L \\
0.5 & 10 & 0.06 & 2 & 0.9 \\
2.0 & 10 & 1.5 & 2 & 1.8 \\
3.0 & 10 & 1 & 3.4 \\
\hline
\end{tabular}

TABLE II

Relation between serial oral dosage of cinchonine and plasma cinchonine $(C)$ and 2-hydroxy cinchonine (CMP) levels

(Plasma drug levels represent average of last three of five days)

\begin{tabular}{|c|c|c|c|c|c|c|c|c|}
\hline \multirow{3}{*}{$\begin{array}{l}\text { Daily } \\
\text { dose }\end{array}$} & \multicolumn{8}{|c|}{ Plasma drug levels (mgm./L) } \\
\hline & \multicolumn{2}{|c|}{ Subject 1} & \multicolumn{2}{|c|}{ Subject 2} & \multicolumn{2}{|c|}{ Subject 3} & \multicolumn{2}{|c|}{ Average } \\
\hline & C & CMP & C & CMP & C & CMP & C & CMP \\
\hline grams & & & & & & & & \\
\hline $\begin{array}{l}0.5 \\
1.0 \\
2.0\end{array}$ & $\begin{array}{l}0.04 \\
0.30 \\
0.62\end{array}$ & $\begin{array}{l}0.65 \\
0.88 \\
2.47\end{array}$ & $\begin{array}{l}0.05 \\
0.31 \\
1.03\end{array}$ & $\begin{array}{l}1.22 \\
1.43 \\
3.48\end{array}$ & $\begin{array}{l}0.07 \\
0.33 \\
0.83\end{array}$ & $\begin{array}{l}0.70 \\
1.11 \\
3.33\end{array}$ & $\begin{array}{l}0.05 \\
0.31 \\
0.83\end{array}$ & \begin{tabular}{|l|}
0.86 \\
1.14 \\
3.09
\end{tabular} \\
\hline
\end{tabular}

When cinchonine is administered by mouth and the plasma analyzed for both cinchonine and 2hydroxy cinchonine (Table II), the two compounds are found in the same relative concentrations as when the drugs are given separately. Compare the 0.5 and 2.0 gram doses in Tables I and II.

Renal excretion of cinchonine and 2-hydroxy cinchonine. The renal clearance of cinchonine and its 2-hydroxy derivative was examined in three subjects with normal kidneys. These data are summarized in Table III. The clearance of the 2hydroxy compound is higher than that of cinchonine itself and approaches the rate of renal plasma flow. As has been found with other organic bases $(9,10)$, the clearance of cinchonine can be depressed by the concomitant administration of large doses of sodium bicarbonate. The clearance of 2-hydroxy cinchonine, however, is not significantly altered by this procedure.

The 24-hour excretion in urine of serially administered cinchonine both as cinchonine and as the 2-hydroxy derivative is shown in Table IV. On the average, only 3.6 per cent of the dose is recovered as cinchonine while 2 -hydroxy cin-

TABLE III Renal clearance of cinchonine $(C)$ and 2-hydroxy
cinchonine (CMP)

(On oral dosage cinchonine, same three subjects)

\begin{tabular}{c|c|c|c}
\hline \hline \multirow{2}{*}{ Group } & $\begin{array}{c}\text { Number of } \\
\text { experiments }\end{array}$ & \multicolumn{2}{|c}{ Average clearance, ml./min. } \\
\cline { 2 - 4 } & & C & CMP \\
\hline Without $\mathrm{NaHCO}_{3}$ & 5 & 193 & 521 \\
With $\mathrm{NaHCO}_{3}$ & 8 & 93 & 609 \\
\hline
\end{tabular}


TABLE IV

24-Hour excretion of cinchonine $(C)$ and 2-hydroxy cinchonine (CMP) on serial oral dosage of cinchonine

(Excretion values represent average of last three of five days on each dose)

\begin{tabular}{|c|c|c|c|c|c|c|c|c|c|c|c|}
\hline \multirow{3}{*}{$\begin{array}{c}\text { Daily } \\
\text { dose }\end{array}$} & \multicolumn{9}{|c|}{24 Hour excretion, milligrams } & \multirow{2}{*}{\multicolumn{2}{|c|}{$\begin{array}{l}\text { Average } \\
\text { per cent } \\
\text { daily dose } \\
\text { recovered }\end{array}$}} \\
\hline & \multicolumn{3}{|c|}{ Subject 1} & \multicolumn{3}{|c|}{ Subject 2} & \multicolumn{3}{|c|}{ Subject 3} & & \\
\hline & Creatinine & C & CMP & Creatinine & C & CMP & Creatinine & C & CMP & C & CMP \\
\hline \multirow[t]{2}{*}{$\begin{array}{c}\text { grams } \\
0.5 \\
1.0 \\
2.0\end{array}$} & \multirow[t]{2}{*}{$\begin{array}{l}1,980 \\
2,010 \\
1,700\end{array}$} & \multirow[t]{2}{*}{$\begin{array}{r}11 \\
35 \\
124\end{array}$} & \multirow[t]{2}{*}{$\begin{array}{r}319 \\
584 \\
1,070\end{array}$} & \multirow[t]{2}{*}{$\begin{array}{l}2,020 \\
1,870 \\
1,600\end{array}$} & \multirow[t]{2}{*}{$\begin{array}{l}11 \\
39 \\
82\end{array}$} & \multirow[t]{2}{*}{$\begin{array}{r}306 \\
468 \\
1,200\end{array}$} & $\begin{array}{l}1,740 \\
1,740 \\
1,710\end{array}$ & $\begin{array}{l}10 \\
44 \\
83\end{array}$ & $\begin{array}{r}243 \\
367 \\
1,260\end{array}$ & $\begin{array}{l}2.0 \\
3.9 \\
4.8\end{array}$ & $\begin{array}{l}57.8 \\
47.3 \\
60.5\end{array}$ \\
\hline & & & & & & & \multicolumn{3}{|c|}{ Average: } & 3.6 & 55.2 \\
\hline
\end{tabular}

chonine accounts for 55 per cent of the dose. When 2-hydroxy cinchonine alone is administered in the same fashion, only 34 per cent is recovered as such (Table V). All the subjects shown in Table $\mathrm{V}$ had active vivax malaria at the time of the observations. In another single experiment only 29 per cent of a single oral dose of 2 grams 2 hydroxy cinchonine was recovered in the urine excreted by a normal subject during the subsequent 48 hours.

\section{Antimalarial activity}

2-hydroxy cinchonine exhibited a definite but limited antimalarial activity when tested against blood-induced $\mathrm{McC}$ oy strain vivax malaria. These data are summarized in Table VI. A daily dose of 3 grams for four days and a mean plasma drug level of $3.4 \mathrm{mgm}$. per liter were required to effect complete eradication of the trophozoites. A daily dose of $0.5 \mathrm{gram}$ and mean plasma drug levels of 0.7 and $1.1 \mathrm{mgm}$. per liter had no effect. Intermediate doses and plasma drug levels had only partial effects. In contrast, daily doses of 1 gram of cinchonine for four days and mean plasma cinchonine levels as low as $0.1 \mathrm{mgm}$. per liter con-

TABLE V

Renal excretion of 2-hydroxy cinchonine on serial oral dosage of 2-hydroxy cinchonine

(Excretion values represent average of last three of four days on drug)

\begin{tabular}{ccc}
$\begin{array}{c}\text { Daily } \\
\text { dose } \\
\text { grams }\end{array}$ & $\begin{array}{c}\text { Number of } \\
\text { subjects }\end{array}$ & $\begin{array}{c}\text { Average } \\
\text { per cent } \\
\text { daily dose } \\
\text { recovered }\end{array}$ \\
\hline $\begin{array}{l}0.5 \\
3.0\end{array}$ & 2 & 34 \\
& 1 & $\frac{35}{34}$
\end{tabular}

sistently eradicated the trophozoites of the same strain of malaria (4). Daily doses of cinchonine as low as 0.5 gram and plasma drug levels less than $0.05 \mathrm{mgm}$. per liter exerted definite effects.

\section{DISCUSSION}

Equivalent plasma 2-hydroxy cinchonine levels are achieved on any given oral dosage of either cinchonine or of the 2-hydroxy compound itself. The plasma 2-hydroxy cinchonine levels are considerably higher than the corresponding plasma cinchonine levels. The differences in plasma cinchonine and 2-hydroxy cinchonine levels are not due to variations in gastro-intestinal absorption. Tissue localization was not specifically examined but it has been demonstrated in dogs that this factor is not important in determining variations in plasma drug concentrations among the cinchona alkaloids (11).

The binding on plasma protein is slightly less for 2-hydroxy cinchonine than for cinchonine, while the rate of renal excretion of the 2-hydroxy

TABLE VI

Antimalarial activity of 2-hydroxy cinchonine

(Blood-induced McCoy vivax malaria-drug. administered four days)

\begin{tabular}{|c|c|c|c|c|c|}
\hline \multirow{2}{*}{ Subject } & \multirow{2}{*}{$\begin{array}{l}\text { Daily } \\
\text { dose }\end{array}$} & \multirow{2}{*}{$\begin{array}{c}\text { Mean } \\
\text { plasma } \\
\text { drug } \\
\text { level }\end{array}$} & \multicolumn{3}{|c|}{ Class of therapeutic effect } \\
\hline & & & I & II & III \\
\hline $\begin{array}{l}1 \\
2 \\
3 \\
4 \\
5\end{array}$ & $\begin{array}{c}\text { grams } \\
3.0 \\
2.0 \\
2.0 \\
0.5 \\
0.5\end{array}$ & $\begin{array}{c}m g m_{:} / L \\
3.4 \\
2.0 \\
1.5 \\
1.1 \\
0.7\end{array}$ & $\begin{array}{l}\mathbf{x} \\
\mathbf{x}\end{array}$ & $\begin{array}{l}\mathbf{x} \\
\mathbf{x}\end{array}$ & $\mathbf{x}$ \\
\hline
\end{tabular}


cinchonine is considerably higher than that of cinchonine. Both these factors should result in relatively lower plasma 2-hydroxy cinchonine levels.

The differences in plasma drug concentrations, therefore, are probably the result of differences in the rates of metabolism. Cinchonine is apparently metabolized rapidly to the 2-hydroxy compound which in turn is metabolized at a slower rate. These rates of metabolism are reflected by the differences in the daily recoveries of cinchonine and its 2-hydroxy derivative from the urine of subjects given serial oral doses of cinchonine. That 2-hydroxy cinchonine is further metabolized is indicated by the recovery from the urine of only one-third of the administered doses and the recovery of sizable amounts of a further oxidation product (3). There appears, then, to be little doubt that 2-hydroxy cinchonine represents the first metabolic product of cinchonine and, further, that the main route of cinchonine metabolism goes through 2-hydroxy cinchonine.

Since the plasma 2-hydroxy cinchonine levels achieved in subjects given cinchonine were so much higher than those of cinchonine itself, it was of interest to determine the relative antimalarial activity of the 2-hydroxy derivative. On the basis of oral dosage, the 2-hydroxy cinchonine was only one-fifth as active as its parent compound. Furthermore, it required a mean plasma 2-hydroxy cinchonine concentration of $3.4 \mathrm{mgm}$. per liter to achieve the same antimalarial effect observed at mean plasma cinchonine levels of only $0.1 \mathrm{mgm}$. per liter. ${ }^{7}$

It may be concluded that the 2 -hydroxy compound plays a negligible role in the antimalarial effect achieved when cinchonine is administered, in spite of the fact that much more of the metabolic product than of the parent compound is present at any given time. These observations, together with the demonstration that the main route of cinchonine metabolism proceeds through the 2-hydroxy derivative, indicate that cinchonine itself is the active antimalarial agent. Its rapid rate of metabolism, therefore, may be one of the important factors that limits its activity. This

7 It is of interest to note that 2-hydroxy cinchonine is only one-fifth as active as cinchonine against $P$. falciparum trophozoites when assayed for antimalarial effect by a test tube technique (12). situation does not necessarily hold for the other cinchona alkaloids.

\section{SUMMARY}

1. Of orally administered cinchonine, less than 5 per cent can be recovered in the urine as such, and more than 50 per cent, as the 2-hydroxy derivative.

2. Higher plasma 2-hydroxy cinchonine than cinchonine levels are achieved when cinchonine alone is administered or when equal doses of the two drugs are given.

3. The differences in plasma drug levels and urine excretions of cinchonine and 2-hydroxy cinchonine are chiefly the result of the more rapid rate of metabolism of cinchonine.

4. The main route of cinchonine metabolism proceeds through the 2-hydroxy derivative, its first metabolic product.

5. On the basis of plasma drug levels, 2-hydroxy cinchonine is only one-tenth as active an antimalarial as cinchonine.

6. The major portion of the antimalarial effect achieved when cinchonine is administered resides in cinchonine itself, and not in any of its metabolic products.

\section{BIBLIOGRAPHY}

1. Kelsey, F. E., and Oldham, F. K., Studies on antimalarial drugs. The distribution of quinine oxidase in animal tissues. J. Pharmacol. \& Exper. Therap., 1943, 79, 77.

2. Knox, W. E., The quinine-oxidizing enzyme and liver aldehyde oxidase. J. Biol. Chem., 1946, 163, 699.

3. Brodie, B. B., Baer, J. E., and Craig, L. C., Cinchona alkaloids: 4. Metabolic products in human urine. Foderation Proc., 1946, 5, 168.

4. Taggart, J. V., Earle, D. P., Jr., Berliner, R. W., Zubrod, C. G., Welch, W. J., Wise, N. B., Schroeder, E. F., London, I. M., and Shannon, J. A., Studies on the chemotherapy of the human malarias. III. The physiological disposition and antimalarial activity of the cinchona alkaloids. J. Clin. Invest., 1948, 27, Suppl., 80.

5. Koepfli, J. B., Personal communication.

6. Fisher, S. H., Troast, L., Waterhouse, A., and Shannon, J. A., The relation between chemical structure and physiological disposition of a series of substances allied to sulfanilamide. J. Pharmacol. \& Exper. Therap., 1943, 79, 373.

7. Shannon, J. A., Earle, D. P., Jr., Berliner, R. W., and Taggart, J. V., Studies on the chemotherapy 
of the human malarias. I. Method for the quantitative assay of suppressive antimalarial action in vivax malaria. J. Clin. Invest., 1948, 27, Suppl., 66.

8. Brodie, B. B., Udenfriend, S., and Dill, W., A scheme for the analysis of basic organic compounds in biological tissues. 5. Estimation of compounds by salt formation with methyl orange. J. Biol. Chem., 1947, 168, 335.

9. Jailer, J. W., Rosenfeld, M., and Shannon, J. A., The effect of alkali and acid on the renal excretion of quinacrine, chloroquine and santoquine. J. Clin. Invest., 1947, 26, 1168.

10. Army Malaria Research Unit, Oxford, Factors affecting the excretion of mepacrine in the urine. Ann. Trop. Med., 1945, 39, 53.

11. Hiatt, E. P., and Quinn, G. P., The distribution of quinine, quinidine, cinchonine and cinchonidine in fluids and tissues of dogs. J. Pharmacol. \& Exper. Therap., 1945, 83, 101.

12. Berliner, R. W., Personal communication. 